\title{
Functional Genes for Cellobiose Utilization in Natural Isolates of Escherichia coli
}

\author{
BARRY G. HALL* AND WESLEY FAUNCE III $\dagger$ \\ Molecular and Cell Biology Department, University of Connecticut, Storrs, Connecticut 06268
}

Received 17 October 1986/Accepted 7 March 1987

\begin{abstract}
The genes for utilization of cellobiose are normally cryptic in both laboratory strains and natural isolates of Escherichia coli. A survey of natural isolates of $E$. coli reveals that functional genes for cellobiose utilization, while rare, are present. The fraction of $E$. coli that utilized cellobiose ranged from $<0.01 \%$ in human fecal samples to $7 \%$ in fecal samples obtained from horses. Samples obtained from sheep, cows, dogs, and pigs contained 0.1 to $0.5 \%$ cellobiose-positive $E$. coli. Neither the previously identified cel genes nor the bgl genes from $E$. coli K-12 were expressed during growth on cellobiose by any of the 14 naturally occurring Cel ${ }^{+}$isolates that were tested. All of the naturally occurring $\mathrm{Cel}^{+}$isolates possessed a cel operon, but all were deleted for the major portion of the $b g l$ operon. The functional $\mathrm{cel}^{+}$genes from these natural isolates differed from the mutationally activated $\mathrm{cel}^{+}$genes obtained in earlier studies in that (i) the mutationally activated $\mathrm{cel}^{+}$genes were temperature sensitive, while the functional genes were not, and (ii) transport of cellobiose was inducible in the strains carrying functional $\mathrm{cel}^{+}$genes, while it was expressed constitutively in strains carrying mutationally activated genes.
\end{abstract}

The cellobiose utilization system of Escherichia coli is being used as a model system to investigate the evolutionary basis for the maintenance of cryptic genes in microbial populations. Cryptic genes are phenotypically silent DNA sequences that are not normally expressed during the lifetime of the organism but may be expressed after a mutation, the mobilization of an insertion element, or some other genetic event. The literature provides a variety of examples of activation of cryptic genes by mutations selected in the laboratory (4). Since cryptic genes make no positive contribution to the fitness of the organism, it might be expected that they would eventually be lost due to the accumulation of inactivating mutations. Cryptic genes would therefore be expected to be quite rare. This, however, is not the case. Selection for "novel" functions has revealed the presence of cryptic genes in gram-positive and gram-negative bacteria and even in Saccharomyces cerevisiae (10). In a model presented to account for the persistence of cryptic genes, three alternative states of a gene were considered: functional alleles, which are expressed under appropriate circumstances; cryptic alleles, which are not expressed but can revert to a functional state by mutation; and nonfunctional alleles, which are irreversibly inactivated (4). It was suggested that functional alleles are advantageous in one environment, while cryptic and nonfunctional alleles are advantageous in some other environment. Specifically, we suggested that in the normal environment functional alleles would be disadvantageous, whereas in an infrequently encountered alternative environment it would be advantageous to possess a functional allele. Two different analyses of the model indicated that, under these circumstances, fluctuation between these two environments would maintain all three alleles in a population $(4,7)$.

$E$. coli do not normally utilize the naturally occurring $\beta$-glucoside sugars arbutin, salicin, and cellobiose $(1,12-14)$.

\footnotetext{
* Corresponding author.

$\dagger$ Present address: Department of Biochemistry and Molecular Biology, College of Medicine, J. Hillis Miller Health Center, University of Florida, Gainesville, FL 32610.
}

$\beta$-Glucoside-utilizing mutants of $E$. coli $\mathrm{K}-12$ may arise as a consequence of mutations in either the $b g l$ operon, in which case the mutants utilize arbutin and salicin $(13,14)$, or in the cel operon, in which case they utilize arbutin, salicin, and cellobiose $(2,5,6)$. The cel operon is located at $37.8 \mathrm{~min}$ on the map of $E$. coli $\mathrm{K}-12$ (5) and encodes a transport protein and a hydrolase, both of which must be active for the organism to utilize $\beta$-glucosides $(1,6)$. The cel operon is not expressed in wild-type $E$. coli $\mathrm{K}-12$ strains, but is expressed constitutively in decryptified $\mathrm{cel}^{+}$mutants $(5,6)$. We have cloned the genes of the cel operon, and molecular studies of the structure and regulation of this operon are in progress.

A requirement of the model for retention of cryptic genes is that conditions must exist in the normal environment that select against the functional allele (4). For $E$. coli $\mathrm{K}-12$ the presence of both cellobiose and an alternative carbon source such as glycerol in the growth medium strongly selected against $\mathrm{cel}^{+}$but not against cryptic (wild-type) alleles (2). We have extended these studies to include natural isolates of $E$. coli (1). None of the 71 natural isolates in the ECOR $(E$. coli Reference) collection (9) was able to utilize any $\beta$ glucoside sugars, but 66 of the strains yielded spontaneous $\beta$-glucoside-positive mutants, and 45 of these strains yielded cellobiose-positive mutants. Since only five strains failed to yield $\beta$-glucoside-positive mutants, only $7 \%$ of this collection contained exclusively nonfunctional alleles. A subset of the mutant isolates was tested for synthesis of $c e l$ and $b g l$ mRNA by probing with those specific DNA sequences. Although examples of both $\mathrm{cel}^{+}$and $\mathrm{bgl}^{+}$mutants of these natural isolates were obtained, several $\beta$-glucoside-positive mutants failed to express either of the two identified operons. It was concluded that the population of $E$. coli includes at least four different gene clusters for utilization of $\beta$-glucoside sugars and that all of these are cryptic in wild-type strains (1).

The model predicts that all three kinds of alleles, functional, cryptic, and nonfunctional, should be found in natural populations. We lack sufficient information about the mutation rates and fitnesses of these alleles in natural environments to predict the relative frequencies of these alleles; 
TABLE 1. $\mathrm{Cel}^{+}$E. coli strains

\begin{tabular}{|c|c|c|}
\hline Strain & Source & Reference \\
\hline RM30 & Camel & 8 \\
\hline RM48B & Feral pig & 8 \\
\hline WF211A3, WF247A & Horse & This study \\
\hline GD24, GD31 & Cow & This study \\
\hline GD36, GD47 & Dog & This study \\
\hline GD50, GD55 & Sheep & This study \\
\hline GD84, GD88 & Pig & This study \\
\hline $\begin{array}{l}\text { B75, B152, B289, } \\
\text { B419 }\end{array}$ & Baboon & 12 \\
\hline MK2 & Laboratory, E. coli $\mathrm{K}-12$ & 5 \\
\hline NIM351 & $\begin{array}{l}\text { Laboratory, } \mathrm{Cel}^{+} \text {mutant of } \\
\text { ECOR strain } 35\end{array}$ & 2 \\
\hline NIM461 & $\begin{array}{l}\text { Laboratory, } \mathrm{Cel}^{+} \text {mutant of } \\
\text { ECOR strain } 46\end{array}$ & 2 \\
\hline NIM481, NIM482 & $\begin{array}{l}\text { Laboratory, } \mathrm{Cel}^{+} \text {mutants of } \\
\text { ECOR strain } 48\end{array}$ & 2 \\
\hline NIM701 & $\begin{array}{l}\text { Laboratory, } \mathrm{Cel}^{+} \text {mutant of } \\
\text { ECOR strain } 7\end{array}$ & 2 \\
\hline
\end{tabular}

however, the failure to detect any functional cellobiose utilization genes among 71 natural isolates was somewhat surprising. There are a variety of possible explanations for the failure to detect any functional cellobiose utilization genes in the ECOR collection, including (i) functional alleles could be very rare and (ii) the frequency of functional alleles could depend strongly on the host from which the strains were isolated. Routman et al. (12) found that the number of sugars utilized by natural $E$. coli isolates varied strongly with the host from which the isolates were obtained. In particular, the $\beta$-glucoside sugar salicin was not utilized by any strains from the ECOR collection, but was utilized by $13 \%$ of the isolates from a human-associated tribe or yellow baboons and by $41 \%$ of the isolates from a tribe of non-humanassociated baboons. While the ECOR collection includes samples from a variety of hosts, the majority (41 strains) were obtained from humans, and most of the animal hosts were in zoos, i.e., human-associated.

The goals of this study were to determine the frequencies of cellobiose-utilizing $E$. coli in fecal samples from a variety of hosts and to compare the properties of these functional $\mathrm{cel}^{+}$genes with those of "decryptified" $\mathrm{cel}^{+}$genes.

\section{MATERIALS AND METHODS}

$E$. coli strains. The strains used in this study are listed in Table 1.

Culture media and conditions. Minimal medium was prepared from a phosphate-buffered mineral salts solution (3) plus a sugar as a carbon source. Plates contained $1.5 \%$ agar as a solidifying agent. Glucose and celloboise were used at a $2 \mathrm{~g} /$ liter, and arbutin and salicin were used at $1.1 \mathrm{~g} /$ liter.

Molecular techniques. Methods for the preparation of RNA and genomic DNA, isolation and labeling of probe DNA, and both DNA-DNA and RNA-DNA hybridizations have been described (1). The cel-specific probe was made from the 4.2-kilobase (kb) $\mathrm{HpaI}$ fragment of plasmid pUF564 (2), and the $b g l$-specific probes were made from either the 3.5-kb HindIII fragment or the 12.0-kb EcoRI fragment of plasmid pAR6 (11).

Growth rates. Cultures were grown overnight, with constant aeration, in minimal medium containing a limiting (0.1 g/liter) concentration of glucose. Exhaustion of the glucose limits growth to a density of about $10^{8}$ cells $\mathrm{ml}^{-1}$. Either cellobiose or glucose was added to the cultures, and the increase in turbidity was monitored with a Gilford Stasar II spectrophotometer at $600 \mathrm{~nm}$. The growth rates were calculated from the slope of the least-squares fit of $\ln A_{600}$ versus time in hours. In all cases the standard error of the growth rate was less than $10 \%$ of the reported value.

Sugar transport rates. The rates of glucose and cellobiose transport were determined by measuring the sugardependent release of pyruvate from phosphoenolpyruvate at $30^{\circ} \mathrm{C}$ by permeabilized cells by continuous spectrophotometric measurement of NADH oxidation in a lactate dehydrogenase-coupled reaction as described previously (6). Rates are reported as nanomoles of sugar transported per minute per $10^{9}$ cells.

Estimation of frequencies of $\mathrm{Cel}^{+} E$. coli in fecal samples. Fresh fecal samples were suspended in a small volume of mineral salts buffer, serially diluted, and plated onto MacConkey lactose and cellobiose minimal medium. The total putative $E$. coli count was determined from the number of $\mathrm{Lac}^{+}$colonies on the MacConkey plates. Fifty $\mathrm{Lac}^{+}$colonies were picked to Simmon citrate agar and to EMB lactose agar. $\mathrm{Lac}^{+}$colonies that were citrate negative and produced the typical green sheen characteristic of $E$. coli on EMB lactose agar were considered authentic $E$. coli, and the fraction of authentic $E$. coli was used to correct the total $E$. coli count. Similarly, the total number of cellobiose-positive organisms was determined from the number of colonies on cellobiose minimal medium. Fifty $\mathrm{Cel}^{+}$colonies were tested on MacConkey lactose, EMB lactose, and Simmon citrate agar, and the proportion that were authentic $E$. coli was determined. A few (three to six) $\mathrm{Cel}^{+} E$. coli from each host were isolated and tested more thoroughly with the Enterotube system (Roche Diagnostic Systems), which includes 12 biochemical tests for identification of members of the Enterobactericeae. In only one case was one of these isolates identified as other than $E$. coli (it was Klebsiella ozaenae isolated from a pig), and five other isolates from pigs proved to be authentic $E$. coli.

\section{RESULTS}

Isolation of $\mathrm{Cel}^{+} \boldsymbol{E}$. coli. The proportion of $\mathrm{Cel}^{+} E$. coli in fecal samples obtained from humans and from a variety of animals on the University of Connecticut farm was determined. A few confirmed $\mathrm{Cel}^{+} E$. coli (Tables 1 and 2) were stored at $-70^{\circ} \mathrm{C}$ for subsequent analysis. Unpaired $t$ tests showed that the proportion of $\mathrm{Cel}^{+} E$. coli in samples from horses was signficantly greater than from any other hosts tested. There were no significant differences among the cow, sheep, pig, and dog samples, but in all of these the proportion of $\mathrm{Cel}^{+} E$. coli was significantly greater than in humanderived samples.

$\mathrm{Cel}^{+} E$. coli from other collections. Fifty $E$. coli from the Routman et al. (12) collection, including 25 salicin-positive $\left(\mathrm{Sal}^{+}\right)$and 25 salicin-negative $\left(\mathrm{Sal}^{+}\right)$isolates, were tested for cellobiose utilization. Four strains were $\mathrm{Cel}^{+}$, and these

TABLE 2. Percentage of $E$. coli that were $\mathrm{Cel}^{+}$

\begin{tabular}{lcc}
\hline Source & $\begin{array}{c}\text { No. of } \\
\text { samples tested }\end{array}$ & $\begin{array}{c}\% \mathrm{Cel}^{+} \\
(\mathrm{mean} \pm \mathrm{SE})\end{array}$ \\
\hline Human & 16 & $<0.01$ \\
Sheep & 10 & $0.16 \pm 0.08$ \\
Dog & 10 & $0.15 \pm 0.10$ \\
Cow & 11 & $0.51 \pm 0.19$ \\
Pig & 12 & $0.15 \pm 0.08$ \\
Horse & 14 & $7.0 \pm 0.022$ \\
\hline
\end{tabular}




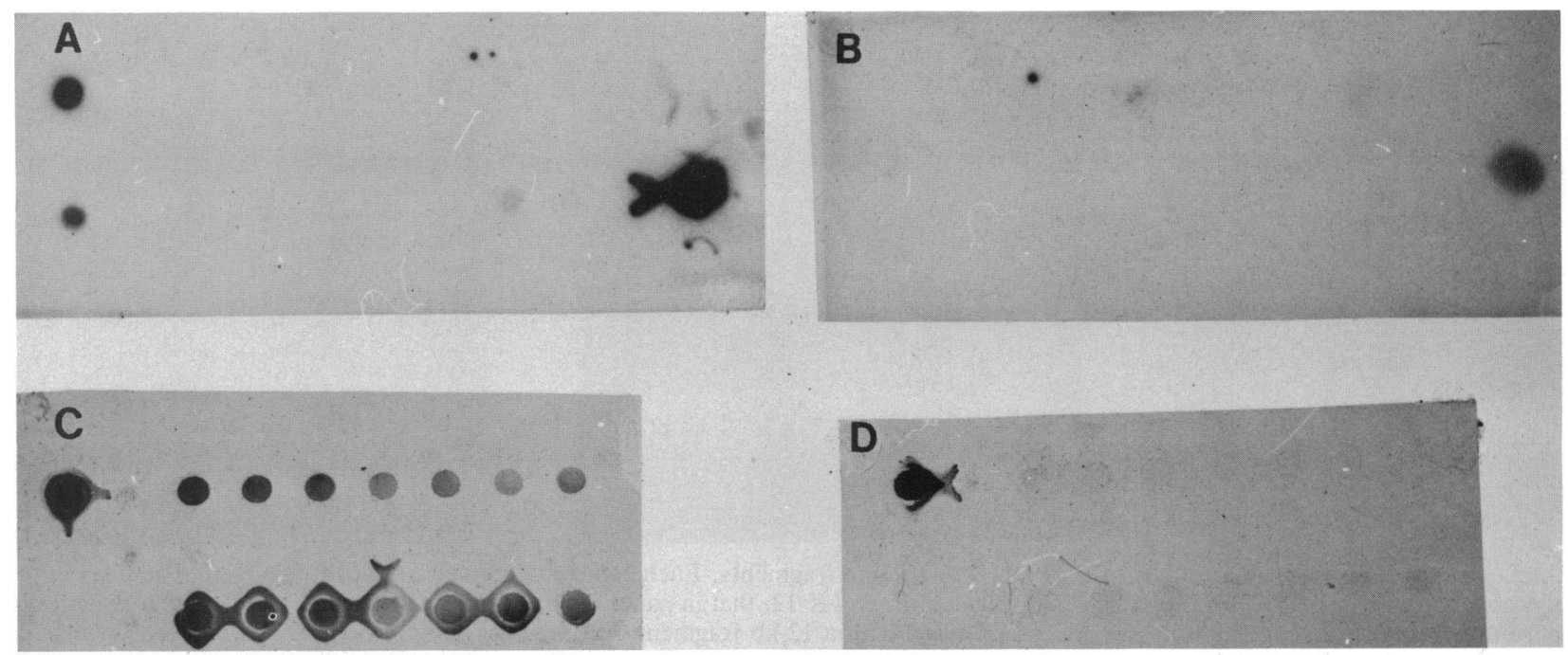

FIG. 1. Hybridization of DNA probes to dot-blots of RNA and DNA. Except as otherwise noted, each sample contained $10 \mu g$ of total RNA from cells grown on cellobiose (A and B) or $10 \mu \mathrm{g}$ of DNA (C and D). The MK2 arbutin sample (A and B only) was taken from cells grown on arbutin, a condition that induces expression of the bgl genes. (A and C) Dot-blots were probed with the 4.2-kb $\mathrm{HpaI}$ fragment of cel genes of $E$. coli K-12. (B and D) Dot-blots were probed with the 3.5-kb HindIII fragment of the bgl operon of E. coli K-12. Each panel: (Left to right, top row: MK2, blank, GD24, GD36, GD50, RM30, B158, and WF211A3. Left to right, bottom row: MK2 (1 $\mu \mathrm{g}$ of RNA in panels A and B only), blank GD31, GD47, GD55, GD88, RM48B, B289, and WF247A. MK2 arbutin is the extreme right in panels A and B.

included a $\mathrm{Sal}^{+}$and a $\mathrm{Sal}^{-}$strain from human-associated baboons and $\mathrm{a} \mathrm{Sal}^{+}$and a $\mathrm{Sal}^{-}$strain from non-humanassociated baboons (Table 1). The $46 \mathrm{Cel}^{-}$strains were streaked onto MacConkey cellobiose medium, and the plates were sealed and incubated for 4 weeks at $30^{\circ} \mathrm{C}$. At the end of that time 29 of the strains had generated spontaneous cellobiose-positive mutants, detected as papillae on the surfaces of the colonies and confirmed by isolation and growth on cellobiose minimal medium. Thus, in that collection of $E$. coli strains from baboons, $8 \%$ of the isolates carried functional $\mathrm{Cel}$ alleles, $30 \%$ carried nonfunctional alleles, and $58 \%$ carried at least one cryptic allele. The frequency of cryptic cel genes was thus very similar to the frequency $(45 \%)$ found in the ECOR collection (1). In addition, two $\mathrm{Cel}^{+} E$. coli, one from a camel and one from a feral pig, originally from the Roger Milkman collection and provided by D. Dykhuizen, were studied (Table 1). The six strains were confirmed as $E$. coli by the Enterotube test.

Characterization of $\mathrm{Cel}^{+} E$. coli. $E$. coli $\mathrm{K}-12$ strain MK2 (5) and two $\mathrm{Cel}^{+}$isolates from each host were grown on cellobiose. RNA was extracted from each of these strains, dot-blotted, and probed with ${ }^{32} \mathrm{P}$-labeled cel and the HindIII fragment of $b g l$ DNA sequences (Fig. 1A and B). As a control for expression of $b g l$, RNA was also extracted from strain MK2 growing on arbutin. The $E$. coli $\mathrm{K}-12$ strain MK2 expressed both the $c e l$ and $b g l$ operons. None of the natural $\mathrm{Cel}^{+}$isolates expressed either cel or $b g l$ mRNA. Genomic DNA from each of the strains was also dot-blotted and probed with the same sequences (Fig. 1C and D). The observation that cel DNA sequences were detected by hybridization to these probes indicates that the failure to detect mRNA was not the consequence of extreme genetic divergence between the genes of the natural isolates and those of $E$. coli $\mathrm{K}-12$. The failure of the HindIII fragment of bgl DNA to hybridize to DNA from any of the natural $\mathrm{Cel}^{+}$ isolates was surprising. To explore the reason for the failure to detect $b g l$ DNA with the $b g l$ HindIII fragment probe, DNA from several strains was digested with restriction endonuclease ClaI, subjected to agarose gel electrophoresis, and transferred to GeneScreen-Plus nylon membranes. Again, the cel probe hybridized to ClaI fragments from all strains, but the $b g l$ HindIII fragment probe hybridized only to fragments from the $E$. coli $\mathrm{K}-12$ strain (Fig. $2 \mathrm{~A}$ and B). The blot shown in Fig. 2B was reprobed with the 12-kb EcoRI fragment from plasmid pAR6 (Fig. 2C). That fragment includes the entire $b g l$ operon plus the phoT, phoS, and $g l m S$ genes that are adjacent to the $b g l$ operon (11). Hybridization of this larger probe to DNA from all of the strains confirmed that the failure to detect $b g l$ mRNA was not due to low sequence homology with the probe. Instead, it appeared that the region corresponding to the $b g l B$ and $b g l S$ genes has been deleted in all of the $\mathrm{Cel}^{+}$natural isolates. The sum of the fragment sizes that hybridized to the $12-\mathrm{kb}$ probe was 6.4 $\mathrm{kb}$ for strain RM30 and $5.8 \mathrm{~kb}$ for strain B289. The size of the deletion in these two strains was therefore at least $5.6 \mathrm{~kb}$. These data indicate that all of the natural isolates are utilizing genes other than $\mathrm{cel}$ or $\mathrm{bgl}$ for growth on cellobiose.

Comparison of natural and decryptified $\mathrm{cel}^{+}$genes. Because cryptic genes are not contributing to the fitness of the organism, random mutations that occur in cryptic genes are expected to be neutral. Some of those mutations might result in the production of temperature-sensitive gene products when the genes are activated by mutation. In contrast, if functional genes are contributing to the fitness of the organism and are under selection for normal functioning in the mammalian gut, then functional alleles would not be expected to specify temperature-sensitive gene products. The growth rates of six decryptified $\mathrm{Cel}^{+}$strains were compared with those of eight functional $\mathrm{Cel}^{+}$isolates from nature. To facilitate comparisons among these unrelated strains, the growth rates on cellobiose were normalized to the growth rates on glucose. This normalization is appropriate because cellobiose is phosphorylated during transport (6) and cleaved to yield glucose plus glucose 6-phosphate. The mutationally activated $\mathrm{Cel}^{+}$strains, on average, grew only $61 \%$ as fast at $37^{\circ} \mathrm{C}$ as they did at $30^{\circ} \mathrm{C}$ (Table 3 ), whereas the naturally functional $\mathrm{Cel}^{+}$strains, on average, grew equally as fast at both temperatures. The effect was more dramatic at $42^{\circ} \mathrm{C}$ 


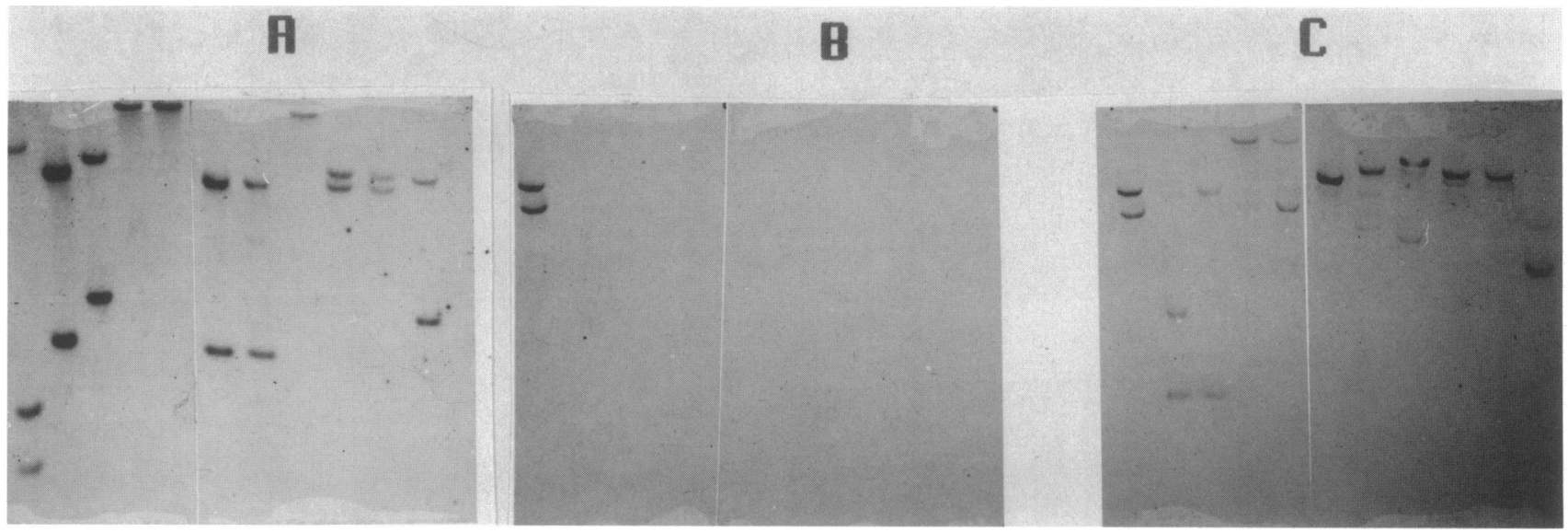

FIG. 2. Hybridization of DNA probes to ClaI DNA restriction fragments. Each sample contained $5 \mu \mathrm{g}$ of total DNA. The filter in panel A was probed with the 4.2-kb HpaI fragment of cel genes of $E$. coli $\mathrm{K}-12$, that in panel B was probed with the 3.5-kb HindIII fragment of the bgl operon of $E$. coli $\mathrm{K}-12$, and that in panel $\mathrm{C}$ was probed with a 12-kb fragment that includes the bgl operon and adjacent genes. Each autoradiogram was cut off $3.5 \mathrm{~cm}$ below the position of the wells. Lanes (left to right in each panel): MK2, B289, B152, GD88, GD84, GD31, GD24, WF247A, WF211A3, and RM30.

(the mutationally activated strains failed to grow on cellobiose) while the naturally functional strains grew at about the same rates as they did at $30^{\circ} \mathrm{C}$. The mutationally activated $\mathrm{cel}^{+}$genes are clearly temperature sensitive, whereas the naturally occurring functional genes are not.

Regulation of $\mathrm{cel}^{+}$genes. The decryptified $\mathrm{cel}$ genes of $E$. coli $\mathrm{K}-12$ are expressed constitutively, as measured by both mRNA hybridizations (1) and cellobiose transport activity (6). Since none of the natural $\mathrm{Cel}^{+}$isolates synthesized mRNA that was homologous to either the cel or the bgl genes of $E$. coli $\mathrm{K}-12$, regulation of gene expression was determined from measurements of cellobiose transport rates. The six natural $\mathrm{Cel}^{+}$alleles were all inducible (Table 4). In contrast, the two mutationally activated alleles, from NIM461 and NIM701, were semiconstitutive. Neither of these strains produces either cel-or $b g l$-specific mRNA when grown on cellobiose (1).

\section{DISCUSSION}

Functional genes for cellobiose utilization were rare in the populations of $E$. coli that we examined. The frequency of $\mathrm{Cel}^{+}$isolates ranged from $7 \%$ in horses down to $<0.01 \%$ in humans. The failure to find any $\mathrm{Cel}^{+}$isolates in the ECOR collection is explained both by the overall rarity of these genes and by the predominance of human-derived isolates in the ECOR collection.

The observation that none of the natural or wild-type $\mathrm{Cel}^{+}$ genes corresponded to either the cel or $b g l$ genes of $E$. coli $\mathrm{K}-12$ is consistent with our earlier suggestion (1) that $E$. coli populations include at least four gene systems for the metabolism of $\beta$-glucoside sugars.

The observation that all of the $\mathrm{Cel}^{+}$isolates contained a deletion of the $b g l$ operon is quite curious. The diversity in restriction patterns among the 11 strains (Fig. 2) shows that

TABLE 3. Growth rates of naturally functional and mutationally activated $\mathrm{Cel}^{+}$strains

\begin{tabular}{|c|c|c|c|c|c|c|c|c|c|}
\hline \multirow{3}{*}{ Strain } & \multicolumn{6}{|c|}{ Growth rate $\left(h^{-1}\right)$} & \multirow{2}{*}{\multicolumn{3}{|c|}{ Normalized rate on cellobiose ${ }^{a}$}} \\
\hline & \multicolumn{3}{|c|}{ Glucose } & \multicolumn{3}{|c|}{ Cellobiose } & & & \\
\hline & $30^{\circ} \mathrm{C}$ & $37^{\circ} \mathrm{C}$ & $42^{\circ} \mathrm{C}$ & $30^{\circ} \mathrm{C}$ & $37^{\circ} \mathrm{C}$ & $42^{\circ} \mathrm{C}$ & $30^{\circ} \mathrm{C}$ & $37^{\circ} \mathrm{C}$ & $42^{\circ} \mathrm{C}$ \\
\hline \multicolumn{10}{|c|}{ Mutationally activated } \\
\hline NIM351 & 0.41 & 0.64 & 0.62 & 0.17 & $<0.008$ & $<0.008$ & 0.41 & $<0.008$ & $<0.008$ \\
\hline NIM461 & 0.33 & 0.42 & 0.38 & 0.26 & 0.24 & $<0.008$ & 0.80 & 0.58 & $<0.008$ \\
\hline NIM481 & 0.59 & 0.69 & 0.52 & 0.13 & 0.12 & $<0.008$ & 0.22 & 0.18 & $<0.008$ \\
\hline NIM482 & 0.47 & 0.66 & 0.54 & 0.20 & 0.21 & $<0.008$ & 0.43 & 0.31 & $<0.008$ \\
\hline NIM701 & 0.66 & 0.84 & 0.76 & 0.44 & 0.35 & $<0.008$ & 0.66 & 0.42 & $<0.008$ \\
\hline MK2 & 0.43 & 0.53 & 0.51 & 0.21 & 0.21 & $<0.008$ & 0.48 & 0.39 & $<0.008$ \\
\hline \multicolumn{10}{|c|}{ Naturally functional } \\
\hline B75 & 0.54 & 0.79 & 0.73 & 0.50 & 0.68 & 0.71 & 0.92 & 0.86 & 0.98 \\
\hline B158 & 0.57 & 0.75 & 0.62 & 0.53 & 0.61 & 0.58 & 0.93 & 0.82 & 0.94 \\
\hline B289 & 0.56 & 0.80 & 0.75 & 0.52 & 0.67 & 0.64 & 0.92 & 0.84 & 0.85 \\
\hline B419 & 0.37 & 0.45 & 0.39 & 0.50 & 0.65 & 0.57 & 1.38 & 1.43 & 1.48 \\
\hline RM30 & 0.60 & 0.6 & 0.35 & 0.55 & 0.70 & 0.63 & 0.92 & 1.17 & 1.81 \\
\hline RM48B & 0.52 & 0.66 & 1.14 & 0.48 & 0.64 & 0.90 & 0.92 & 0.96 & 0.79 \\
\hline WF211A3 & 0.62 & 0.91 & 0.92 & 0.60 & 0.80 & 0.83 & 0.97 & 0.88 & 0.90 \\
\hline WF247A & 0.61 & 0.85 & 0.75 & 0.53 & 0.69 & 0.57 & 0.86 & 0.81 & 0.76 \\
\hline
\end{tabular}

\footnotetext{
${ }^{a}$ Normalized rates are growth rates on cellobiose divided by the growth rates on glucose at the same temperature.
} 
TABLE 4. Sugar transport by natural and mutationally activated $\mathrm{Cel}^{+}$E. coli

\begin{tabular}{lccccc}
\hline & \multicolumn{3}{c}{ Transport rate $^{a}$ (nmol/min per 10 $0^{9}$ cells) } \\
\cline { 2 - 3 } \cline { 5 - 6 } \cline { 5 - 6 } & \multicolumn{2}{c}{ Glucose $^{b}$} & \multicolumn{2}{c}{ Cellobiose $^{b}$} \\
\cline { 2 - 3 } \cline { 5 - 6 } Glucose $^{c}$ & Cellobiose $^{c}$ & & Glucose $^{c}$ & Cellobiose $^{c}$ \\
\hline B158 & 3.5 & $<0.01$ & & 8.6 & 4.5 \\
B289 & 11.7 & $<0.01$ & & 5.3 & 4.9 \\
WF211A3 & 7.7 & $<0.01$ & & 12.0 & 11.0 \\
WF247A & 5.9 & $<0.01$ & & 12.5 & 4.3 \\
RM30 & 5.4 & $<0.1$ & & 8.1 & 4.0 \\
RM48B & 7.8 & $<0.1$ & & 5.1 & 6.9 \\
NIM461 & 5.5 & 0.34 & & 2.1 & 1.3 \\
NIM701 & 3.5 & 0.47 & & 3.4 & 1.5 \\
\hline
\end{tabular}

${ }^{a}$ Means of triplicate assays. In no case was the range more than $15 \%$ of the mean value.

${ }^{b}$ Carbon sources.

c Substrates (4 mM).

we are not dealing with repeated isolations of the same strain. We do not yet known whether all of these strains contain the same deletion, which would indicate that they are all descended from the same common ancestor, or whether deletion of $b g l$ has occurred repeatedly. Given the diverse origins of these strains, the strong correlation between the deletion of $b g l$ and the $\mathrm{Cel}^{+}$phenotype suggests an interaction between expression of the genes for cellobiose utilization and the presence of the $b g l$ operon so that the two cannot coexist for long. More extensive characterization of the $b g l$ deletion and a survey for its presence in several collections of natural $E$. coli isolates is in progress.

We originally distinguished three states of alleles: functional, cryptic, and nonfunctional. It now seems reasonable to make a distinction between two categories of functional alleles: those that were functional when the organism was isolated from nature, which we shall call naturally functional, and those that were cryptic when the organism was isolated and were activated by a mutation in the laboratory, which we shall call mutationally activated alleles. This distinction appears to reflect more than just history. Naturally functional alleles seem to be inducible, whereas mutationally activated alleles are constitutive or semiconstitutive. Mutationally activated alleles are temperature sensitive, while naturally functional alleles are not. The temperature sensitivity of mutationally activated alleles is consistent with the notion that silent genes accumulate mutations freely.

These observations are consistent with our model $(4,7)$ for the retention of cryptic genes. Naturally functional cellobiose utilization alleles are rare, but there is an environment, perhaps the lower intestine of horses, that appears to favor them. We originally envisioned occasional environmental changes that would create temporary conditions favoring functional alleles. It now seems likely that such changes can also be accounted for by migration between different environments (different hosts) which select differently for or against functional cel alleles. At the one extreme for $E$. coli, horses appear to favor $\mathrm{cel}^{+}$alleles, and humans appear to select strongly against them. It is not clear why horses, cows, and sheep, all of which derive energy from cellulose degradation, should differ so much in the frequency of $\mathrm{Cel}^{+} E$. coli in their feces.

Together with earlier studies $(1,2)$, this study provides a picture of an $E$. coli population in which there are several gene systems for utilization of cellobiose and other $\beta$ glucoside sugars. In any one strain, perhaps half of those genes will have been inactivated (rendered nonfunctional), while the others are highly likely to be silent and accumulating mutations that are leading toward extinction of the gene (1). The occasional selection of $\mathrm{Cel}^{+}$clones as the result of either environmental fluctuation or migration into a favorable environment is expected to generate population bottlenecks and result in periodic selection that repeatedly eliminates much neutral variation. This is consistent with the picture of the structure of $E$. coli populations that has been generated by studies on electrophoretic variation (15).

\section{ACKNOWLEDGMENTS}

We gratefully acknowledge the participation of Glenn Doughty in the collection and identification of many of the natural isolates of $E$. coli that are described in this study. We are grateful to Paul W. Betts for his expert technical assistance. We thank Dan Dykhuizen for the gift of several strains.

This work was supported by Public Health Service grants AI-14766 and GM-37110 from the National Institutes of Health.

\section{LITERATURE CITED}

1. Hall, B. G., and P. W. Betts. 1987. Cryptic genes for cellobiose utilization in natural isolates of Escherichia coli. Genetics 115:431-439.

2. Hall, B. G., P. W. Betts, and M. Kricker. 1986. Maintenance of the cellobiose utilization genes of Escherichia coli in a cryptic state. Mol. Biol. Evol. 3:389-402.

3. Hall, B. G., and D. L. Hartl. 1974. Regulation of newly evolved enzymes. I. Selection of a novel lactase regulated by lactose in Escherichia coli. Genetics 76:391-400.

4. Hall, B. G., S. Yokoyama, and D. H. Calhoun. 1983. Role of cryptic genes in microbial evolution. Mol. Biol. Evol. 1:109-124.

5. Kricker, M., and B. G. Hall. 1984. Directed evolution of cellobiose utilization in Escherichia coli K-12. Mol. Bol. Evol. 1:171-182.

6. Kricker, M., and B. G. Hall. 1987. Biochemical genetics of the cryptic gene system for cellobiose utilization in Escherichia coli K-12. Genetics 115:419-429.

7. Li, W.-H. 1984. Retention of cryptic genes in microbial populations. Mol. Biol. Evol. 1:212-218.

8. Milkman, R. 1973. Electrophoretic variation in Escherichia coli from natural sources. Science 182:1024-1026.

9. Ochman, H., and R. K. Selander. 1984. Standard reference strains of Escherichia coli from natural populations. J. Bacteriol. 157:690-693.

10. Pacquin, C. E., and V. M. Williamson. 1986. Ty insertions at two loci account for most of the spontaneous antimycin A resistance mutations during growth at $15^{\circ} \mathrm{C}$ of Saccharomyces cerevisiae strains lacking ADH1. Mol. Cell. Biol. 6:70-79.

11. Reynolds, A. E., S. Mahadevan, J. Felton, and A. Wright. 1985. Activation of the cryptic bgl operon: insertion sequences, point mutations and changes in superhelicity affect promoter strength. UCLA Symp. Mol. Cell. Biol. New Series 20:265-277.

12. Routman, E., R. D. Miller, J. Phillips-Conroy, and D. L. Hartl. 1985. Antiobiotic resistance and population structure in Escherichia coli from free-ranging African yellow baboons. Appl. Environ. Microbiol. 50:749-754.

13. Schaefler, S. 1967. Inducible system for the utilization of $\beta$ glucosides in Escherichia coli. I. Active transport and utilization of $\beta$-glucosides. J. Bacteriol. 93:254-263.

14. Schaefler, S., and W. K. Maas. 1967. Inducible system for the utilization of $\beta$-glucosides in Escherichia coli. II. Description of mutant types and genetic analysis. J. Bacteriol. 93:264-272.

15. Selander, R. K., and B. R. Levin. 1980. Genetic diversity and structure in Escherichia coli populations. Science 210:545-547. 